\title{
Optimization of moromi fermentation parameters to nutritional content of oyster mushrooms sauce (Pleurotus spp.) by using response surface methodology
}

\author{
1,* Giang, N.T.N., ${ }^{2}$ Khai, T.V. and ${ }^{3}$ Thuy, N.M. \\ ${ }^{1}$ Experimental-practical Area, An Giang University, Vietnam University Ho Chi Minh city, Vietnam \\ ${ }^{2}$ Crop Science Department, An Giang University, Vietnam University Ho Chi Minh city, Vietnam \\ ${ }^{3}$ Food Technology Department, Can Tho University, Vietnam
}

\section{Article history:}

Received: 6 February 2021

Received in revised form: 8

March 2021

Accepted: 21 April 2021

Available Online: 26

September 2021

\section{Keywords:}

Moromi,

Salt concentration,

Fermentation time,

Brine ratio,

Nutritional content,

Oyster mushrooms sauce

\section{DOI:}

https://doi.org/10.26656/fr.2017.5(5).097

\begin{abstract}
Oyster mushrooms are used as raw materials for sauce because of their enhanced nutritious and sensory flavour. The study was aimed to select the optimal parameters of moromi fermentation of oyster mushrooms sauce. Optimizing moromi fermentation from oyster mushrooms by response surface method (RSM) was conducted with 3 factors including salt concentration $(15-25 \% \mathrm{w} / \mathrm{v}$ ), the brine ratio [150-250\% (compared to raw materials, v/w)] and fermentation time (50-70 days). The central composite design used for optimizing the effect of salt concentration, amount of brine and fermentation time showed that the parameters were in agreement with the quadratic regression models well with $\mathrm{R}^{2}>0.95$. Based on the response surface plots, the optimal parameters of moromi fermentation were salt concentration $20 \%(\mathrm{w} / \mathrm{v}$ ), brine ratio $190 \%$ (compared to raw materials, $\mathrm{v} / \mathrm{w}$ ) and 60 days of fermentation time. In the optimized condition, the chemical composition (reducing sugar, amino protein, total acids) and the bioactive compounds ( $\beta$ glucan, total phenolic, total flavonoid) (per $\mathrm{kg}$ of dry matter) of fermentation sauce were $258.94 \mathrm{~g}, 204.76 \mathrm{~g}, 99.06 \mathrm{~g}, 86.57 \mathrm{~g}, 108.32 \mathrm{mg}$ TAE and $93.78 \mathrm{mg}$ QE, respectively.
\end{abstract}

\section{Introduction}

Soy sauce is a widely used product because it is suitable for everyone, especially vegetarians. There are two main methods to produce soy sauce that are chemical hydrolysis and fermentation. The sauce is produced by the fermentation method because it does not have 3-monochloropropane-1,2-diol (3-MCPD) which is formed by the combination of amino acids, glycerin and fatty acids at high temperature in the presence of $\mathrm{HCl}$. Besides, the fermentation technique is an excellent treatment to raise the nutritional as well as the functional properties because of the increasing content of small bioactive compounds (Baek et al., 2008). The soy sauce process consisted of an established two-step fermentation method, namely Koji and moromi (Yang et al., 2017) and Aspergillus oryzae is the main fermenting agent in the production of soy sauce (Yokosuka and Sasaki, 1998). The scientific basis of the hydrolysis process is the use of amylase and protease produced by Aspergillus oryzae to break down starch into saccharose, maltose, glucose and protein into polypeptides, peptides and amino acids. Moromi fermentation is also an important stage because the sauce is still unsatisfactory, and the efficiency is not high if the fermentation technique is not guaranteed. Moreover, the sauce quality is determined by its chemical composition (Gao et al., 2011). Furthermore, Pleurotus spp. is an edible mushroom and has been identified as a vegetable in the world's food system. Carbohydrates and protein are the main components, accounting for 70 to $90 \%$ of dry matter (Mowsumi and Choudhury, 2010). Oyster mushrooms are very helpful for vegetarians because of essential amino acids found in animal proteins such as lysine, methionine, tryptophan (Verma et al., 1987). Carbohydrates included various compounds such as monosaccharides, oligosaccharides and polysaccharides, which play an important role in gastrointestinal activity (Kalac, 2009). Besides, vitamins (B and C), minerals (K, $\mathrm{P}, \mathrm{Se}$ ), bioactive compounds (phenolic, flavonoid, $\beta$ glucan) protected human cells from damage and help improve the immune system (Mowsumi and Choudhury, 2010; Randive, 2012). Eating oyster mushrooms regularly seemed to reduce the risk of obesity, diabetes, and cancer (Verma et al., 1987). To enhance the use of oyster mushrooms and create a sauce that is both nutritious, efficient sensory value and is safe for human health, oyster mushrooms are selected as raw materials. The study was to select the optimal parameters of the moromi fermentation of oyster mushrooms sauce (salt 
concentration, brine ratio and fermentation time) to obtain the highest content of nutrients in sauce by using response surface methodology.

\section{Materials and methods}

\subsection{Prepare the Koji fermentation}

Wheat flour was roasted at $90^{\circ} \mathrm{C}$ for 15 mins. Aspergillus oryzae in the form of spore powder $\left(10^{9}\right.$ $\mathrm{CFU} / \mathrm{g}$ ) was provided by The Institute of Biotechnology Research and Development of Can Tho University (Vietnam), originating from ATCC (American Type Culture Collection)

The Pleurotus spp. mushrooms were harvested from the Experimental Area, on the campus of An Giang University, Vietnam University Ho Chi Minh city, Vietnam. They were then washed with clean water, chopped $(0.5 \times 1 \mathrm{~cm})$, steamed at $90^{\circ} \mathrm{C}$ for $9-10$ mins and cooled at room temperature. A weight of $50 \mathrm{~g}$ mushrooms was mixed with $5 \mathrm{~g}$ roasted wheat flour and $0.015 \mathrm{~g}$ mould powder. The mixture was put into glass glue and incubated at $30^{\circ} \mathrm{C}$ for $30 \mathrm{hrs}$.

Salt, from the Southern Salt Company, is diluted with the concentration $11.5 ; 15 ; 20 ; 25$ and $28.5 \% \mathrm{w} / \mathrm{v}$.

\subsection{Experimental methods}

The optimization of fermentation parameters was designed according to Response Surface Methodology (RSM) using central composite design (CCD) $2^{3}+$ star (the STAGRAPHICS centurion software, version 16.1 was used), including 6 central points and 20 numbers of treatments.

The experiment was conducted with 3 factors including: salt concentration $\left(\mathrm{X}_{1}\right)(15-25 \% \mathrm{w} / \mathrm{v})$, brine ratio $\left(\mathrm{X}_{2}\right)$ [150-250\% (compared to raw materials, $\left.\left.\mathrm{v} / \mathrm{w}\right)\right]$ and fermentation time $\left(\mathrm{X}_{3}\right)$ (50-70 days). Each factor was surveyed with 5 levels, coded from $-\alpha$ to $+\alpha$ (with $\alpha$ $= \pm 1.682$ ). The level of encrypted variables and experimental layout is shown in Table 1 and Table 2.

\subsection{Analytical methods}

\subsubsection{Determination of reducing sugar content}

Reducing sugar content $(\mathrm{g} / \mathrm{kg}$ of dry matter) was measured by the DNS method (Miller, 1959) with some modifications. A volume of $1 \mathrm{~mL}$ of sample was put in the test tube and then $2 \mathrm{~mL}$ of reagent DNS was added.
Table 2. Experimental layout according to central composite design

\begin{tabular}{cccc}
\hline Runs & $\begin{array}{c}\text { Salt concentration } \\
(\% \mathrm{w} / \mathrm{v})\end{array}$ & $\begin{array}{c}\text { Brine ratio }(\% \\
\text { compared to raw } \\
\text { materials })\end{array}$ & $\begin{array}{c}\text { Fermentation } \\
\text { time (days) }\end{array}$ \\
\hline 1 & 0 & 0 & 0 \\
2 & $-\alpha$ & 0 & 0 \\
3 & 0 & 0 & $+\alpha$ \\
4 & 0 & 0 & 0 \\
5 & 0 & $-\alpha$ & 0 \\
6 & -1 & -1 & 1 \\
7 & 0 & 0 & 0 \\
8 & 1 & -1 & 1 \\
9 & -1 & 1 & -1 \\
10 & 0 & $+\alpha$ & 0 \\
11 & 0 & 0 & 0 \\
12 & -1 & 1 & 1 \\
13 & 0 & 0 & 0 \\
14 & $+\alpha$ & 0 & 0 \\
15 & 1 & 1 & -1 \\
16 & 1 & 1 & 1 \\
17 & 0 & 0 & $-\alpha$ \\
18 & -1 & -1 & -1 \\
19 & 1 & -1 & -1 \\
20 & 0 & 0 & 0 \\
\hline
\end{tabular}

This method is based on the oxidation of $\mathrm{C}=\mathrm{O}$ group by 3,5-Dinitrosalicylic acid from a yellow colour to orangered in an alkaline medium. The tubes of the blank, solution of standard glucose and samples were placed in boiling water for 10 mins. After that, $7 \mathrm{~mL}$ of distilled water was added to the tubes. The solution was analysed with an absorption of $575 \mathrm{~nm}$. The concentration of reducing sugar were based on a standard curve of glucose, $\mathrm{y}=23885 \mathrm{x}+0.126\left(\mathrm{R}^{2}=0.9999\right)$, where $\mathrm{y}$ is the absorbance and $\mathrm{x}$ is the concentration of the solution in the tube.

\subsubsection{Determination of amino protein content}

Amino protein content was measured by the Ninhydrin method (Friedman, 2004). Ninhydrin binds with amino acids and undergoes oxidation to release $\mathrm{NH}_{3}, \mathrm{CO}_{2}$ and hydrindantin. $\mathrm{NH}_{3}$ reacts with another ninhydrin molecule and hydrindantin to produce the blue substance diketohydrin (Ruhemanns complex). An aliquot $(1 \mathrm{~mL})$ of the sample was mixed with $0.5 \mathrm{~mL}$ of $0.2 \mathrm{M}$ citrate buffer ( $\mathrm{pH} \mathrm{5}$ ) and $0.2 \mathrm{~mL}$ of $2 \%$ ninhydrin solution. After 30 mins, the mixture was measured at 570 $\mathrm{nm}$. The concentration of amino protein was based on a standard curve of Leucine, $\mathrm{y}=614.820 \mathrm{x}+0.002\left(\mathrm{R}^{2}=\right.$

Table 1. Variable coding and survey levels of salt concentration, brine ratio and fermentation time of moromi fermentation

\begin{tabular}{ccccccc}
\hline \multirow{2}{*}{ Variables } & \multirow{2}{*}{ Codes } & \multicolumn{5}{c}{ Levels } \\
\cline { 3 - 7 } & & $-\alpha$ & -1 & 0 & 1 & $+\alpha$ \\
\hline Salt concentration $(\% \mathrm{w} / \mathrm{v})$ & $\mathrm{X}_{1}$ & 11.5 & 15 & 20 & 25 & 28.5 \\
Brine ratio (\% compared to raw materials) & $\mathrm{X}_{2}$ & 115 & 150 & 200 & 250 & 285 \\
Fermentation time (days) & $\mathrm{X}_{3}$ & 43 & 50 & 60 & 70 & 77 \\
\hline
\end{tabular}


0.9999), where $\mathrm{y}$ is the absorbance and $\mathrm{x}$ is the concentration of the solution in the tube.

\subsubsection{Determination of total acids content}

The total acids content was measured by titration (Erinç et al., 2009). An acid-base titration is a quantitative analytical method to determine the concentration of acid by precisely neutralizing it with a standard solution of a known base concentration $(0.1 \mathrm{~N}$ $\mathrm{NaOH})$. The concentration of total acids is calculated using Equation (1):

$$
A_{x}=\frac{n \times V_{1}}{V_{2} \times V_{3}}
$$

Where $\mathrm{n}$ is the volume of $0.1 \mathrm{~N} \mathrm{NaOH}$ to titrate $(\mathrm{mL}) ; \mathrm{V}_{1}$ is volumetric flask capacity $(\mathrm{mL}) ; \mathrm{V}_{2}$ is the volume of raw sample $(\mathrm{mL})$ and $\mathrm{V}_{3}$ is the volume of diluted sample to titrate $(\mathrm{mL})$.

\subsubsection{Determination of $\beta$-glucan content}

$\beta$-glucan content $(\mathrm{mg} / \mathrm{kg}$ of dry matter) was measured by the Phenol-Sulfuric method (Fournier, 2001). Approximately $5 \mathrm{~mL}$ of sample was mixed with $20 \mathrm{~mL}$ of $96 \%$ ethanol and let at $4^{\circ} \mathrm{C}$ for $24 \mathrm{hrs}$. The solution was filtered with Whatman No. 5B filter paper. Later, $2.5 \mathrm{~mL}$ of filtered solution was added with $2.5 \mathrm{~mL}$ of $1 \mathrm{M} \mathrm{NaOH}$ for $1 \mathrm{hr}$ at $60^{\circ} \mathrm{C}$ and was left at room temperature. About $0.5 \mathrm{~mL}$ of $4 \%(\mathrm{w} / \mathrm{v})$ phenol and 2.5 $\mathrm{mL}$ of $96 \% \mathrm{H}_{2} \mathrm{SO}_{4}$ was then added into the mixture. The solution analysed with the absorption of $490 \mathrm{~nm}$ of the complex of phenol and glucan. The concentration of $\beta$ glucan content was based on a standard curve of glucan, $\mathrm{y}=2745.61 \mathrm{x}+0.0003\left(\mathrm{R}^{2}=0.9999\right)$, where $\mathrm{y}$ is the absorbance and $\mathrm{x}$ is the concentration of the solution in the tube.

\subsubsection{Determination of total phenolic content}

Total phenolic content (mg TAE/kg of dry matter) was determined using Folin-Ciocalteu reagent (Singleton et al., 1999). About $150 \mu \mathrm{L}$ of the sample was mixed with $1200 \mu \mathrm{L}$ of distilled water and $450 \mu \mathrm{L}$ of $5 \%(\mathrm{w} / \mathrm{v})$ $\mathrm{Na}_{2} \mathrm{CO}_{3}$ in a test tube. The mixture was added to $0.1 \mathrm{~mL}$ of Folin-Ciocalteu reagent and left at room temperature for $90 \mathrm{mins}$ to react. Phenolic in the extract reacts with Folin-Ciocalteu to form a blue complex in the alkaline medium that is phosphomolybdenum complex. The concentration of total phenolics was calculated as equal to the standard tannic acid graph (TAE), $\mathrm{y}=0.0021 \mathrm{x}+$ $0.0064\left(\mathrm{R}^{2}=0.9999\right)$, where $y$ is the absorbance and $\mathrm{x}$ is the concentration of the solution in the tube.

\subsubsection{Determination of total flavonoid content}

This assay was performed using the aluminium chloride colourimetric method described by Barros et al.
(2008) with some modifications. The principle related to $\mathrm{AlCl}_{3}$ creating a stable acid complex with the C-4 keto groups and the hydroxyl C-3 or C-5 group of the flavon and flavonol. About $100 \mu \mathrm{L}$ of the sample was added with $1200 \mu \mathrm{L}$ of distilled water and $30 \mu \mathrm{L}$ of $5 \%(w / v)$ $\mathrm{NaNO}_{2}$. After 5 mins, the mixture was mixed with $10 \%$ (w/v) $\mathrm{AlCl}_{3} \cdot \mathrm{H}_{2} \mathrm{O}(60 \mu \mathrm{L})$. Approximately $200 \mu \mathrm{L}$ of $1 \mathrm{M}$ $\mathrm{NaOH}$ and $110 \mu \mathrm{L}$ of water were mixed into the solution. The solution was then measured at $510 \mathrm{~nm}$. The concentration of total flavonoid was calculated as equal to standard quercetin graph $(\mathrm{QE}), \mathrm{y}=8.2634 \mathrm{x}+0.0182$ $\left(\mathrm{R}^{2}=0.9999\right)$, where $\mathrm{y}$ is the absorbance and $\mathrm{x}$ is the concentration of the solution in the tube.

\subsection{Data analysis methods}

Data were collected and processed by STAGRAPHICS Centurion 16.1 software for analysis variance (ANOVA), LSD test to conclude the difference between the average of experiments at $5 \%$ confidence ( $p$ $=0.05$ ) and Microsoft Excel software for calculating and graphing.

The appropriateness of the predicted model when performing optimization is assessed through the correlation coefficient $R^{2}$. Equation optimizing the response surface of general form experiments according

$$
Y=\beta_{0}+\sum_{i=1}^{k} \beta_{i} X_{i}+\sum_{i=1}^{k} \beta_{i i} X_{i}^{2}+\sum_{i=1}^{k} \sum_{j=1}^{k} \beta_{i j} X_{i} X_{j}
$$

to Equation (2).

Where $\mathrm{Y}$ is object function, $\beta_{\mathrm{o}}$ is constant, $\beta_{\mathrm{i}}$ is the linear coefficient, $\beta_{\mathrm{ii}}$ is the square coefficient, $\beta_{\mathrm{ij}}$ is interaction coefficient and $X_{i}, X_{j}$ are survey variables.

\section{Results and discussion}

3.1 The influence of factors (salt concentration, brine ratio and fermentation time) of moromi fermentation on chemical composition

The response surface models showing the effect of salt concentration, brine ratio and fermentation time on reducing sugar, total amino protein and total acids are presented in Figure 1. The results showed that the parameters of the fermentation process all had a quadratic effect on the chemical composition of the fermentation sauce. When increasing the salt concentration, the amount of brine and fermentation time, the content of reducing sugar, amino protein and total acids tended to increase, however, only increased to the optimum point and then decreased gradually. The results of optimal reducing sugar, amino protein and total acids (per kg of dry matter) were 266.14, 206.84 and 101.72 when fermenting at $22.19 \% \mathrm{w} / \mathrm{v}$ of salt concentration, brine supplement of $161.32 \%$ (compared to raw materials, v/w) for 58.29 fermentation days, 


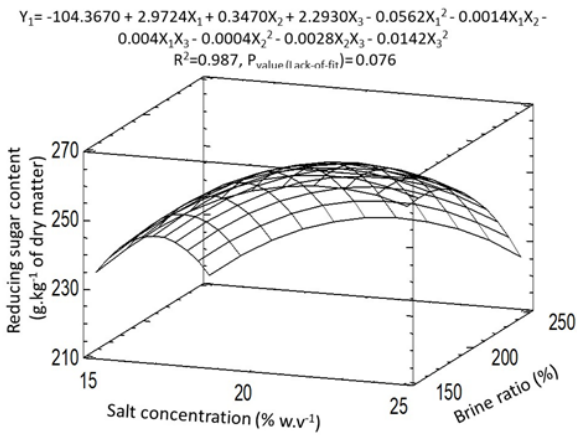

(a)

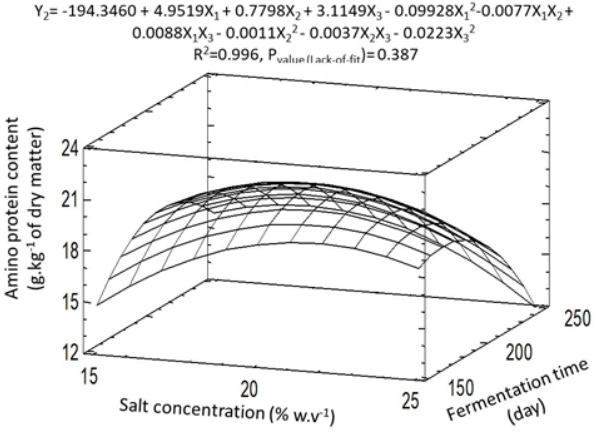

(b)

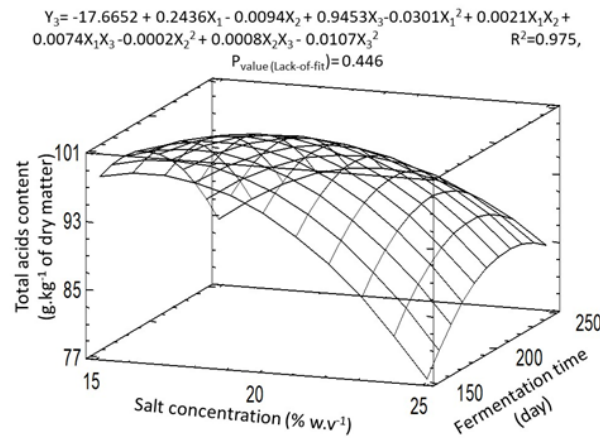

(c)

Figure 1. The response surface plots of (a) reducing sugar, (b) amino protein and (c) total acids influenced by fermentation factors of salt concentration, brine ratio and fermentation time (one of which is kept at the central point)

$20.19 \% \mathrm{w} / \mathrm{v}, 190.52 \%$ for 58.29 days, $16.77 \% \mathrm{w} / \mathrm{v}$, $169.67 \%$ for 56.27 days, respectively. This result showed that the chemical composition in the sauce was made at a salt concentration of $16-22 \%(\mathrm{w} / \mathrm{v}), 160-191 \%$ brine $(\mathrm{v} /$ w) for 56-61 days.

The addition of brine with a high salt concentration in the fermentation is a condition to hinder the development of undesirable putrefactive bacteria during subsequent fermentation (Hui et al., 2004). However, high salt concentration (more than 25\%) inhibited the activity of protease and amylase, therefore, the nutrient contents in sauce decreased ( $\mathrm{Su}$ et al., 2005). Besides, high salt content caused mushroom cells to harden and increase osmotic pressure, thus, reduce the breakdown of enzymes (Beddows, 1985). Furthermore, the brine ratio had a strong influence on product quality. Brine addition is too much to dilute the concentration of nutrients. By contrast, if the supplement of brine is little, the enzyme activities in moromi are reduced and thus the hydrolysis efficiency decreased and the cost of soy sauce was increased. In addition, the fermentation time also determined the effectiveness of the fermentation process. The longer the ageing time was, the more radical the hydrolysis reaction and chemopreventive effect were. Besides, the increasing of reducing sugar and amino protein contents in the sauce is the result of hydrolytic activity of the amylase and protease produced by Aspergillus oryzae (in the Koji fermentation and remained actively during moromi fermentation) (Cui et al., 2014). Moreover, the quality of sauce was determined by amino proteins content and the activity of protease directly affected amino proteins content ( $\mathrm{Lu}$ et al., 2009). Lopetcharat et al. (2001) reported that amino proteins contributed significantly to the aroma of soy sauce. From the results, the amino protein and reducing sugar contents decreased when prolonging the fermentation time. Amylase activity was decreased because the enzyme is denatured in the brine solution when prolonging the ageing time (Chou et al., 1998). In addition, the reduction of amino proteins and reducing sugars in the sauce is also caused by the Maillard reaction between the amino group and glucose. Similarly, the total acids value is an important quality parameter in fermentation food (Lee and Kim, 1995). The increasing total acids during the fermentation process is due to the activity of enzymes into amino proteins, peptides (containing carboxylic chains) and reducing sugars (Shieh et al., 1982). Previous studies had shown that salt was also added into fermented soy sauce from $18-22 \%$, brine ratio $200-250 \%$ (compared to Koji, $\mathrm{v} / \mathrm{w}$ ) for 2-6 months (Wan et al., 2013; Zhao et al., 2018).

The regression equation expressing the relation of the independent variables to the reducing sugar, amino protein and total acids contents were described in Figure 1. A good correlation model required a correlation coefficient $\left(\mathrm{R}^{2}\right)$ to be higher than 0.8 (Guan and Yao, 2008). Besides, a good correlation model needs to be consistent between experimental and theoretical data, so the model with Lack-of-fit without statistical $(p>0.05)$ is essential. Moreover, the degree of compatibility between reducing sugar, amino protein and total acids of experimental and predicted fermentation sauce were expressed in Figure 2. The results showed that the appropriateness of the prediction models with the target functions was very high $\left(\mathrm{R}^{2}>0.97\right)$ and there was high compatibility between experimental and theoretical data $\left(\mathrm{R}^{2}>0.99\right)$.

\subsection{Effect of factors (salt concentration, brine ratio and fermentation time) of moromi fermentation on the content of bioactive compounds}

The process of moromi fermentation also changed the bioactive compounds such as phenolic, flavonoid and $\beta$-glucan of sauce. In Koji fermentation, besides amylase and protease, Aspergillus oryzae also produced a range of enzymes related to the depletion of plant polysaccharides such as hemicellulase, pectinase and lipase (Pinto et al., 2001; Mathivanan et al., 2006). These enzymes are essential to degrade or break down cell walls to allow for the release and extraction of bioactive compounds (Pinelo et al., 2006). 


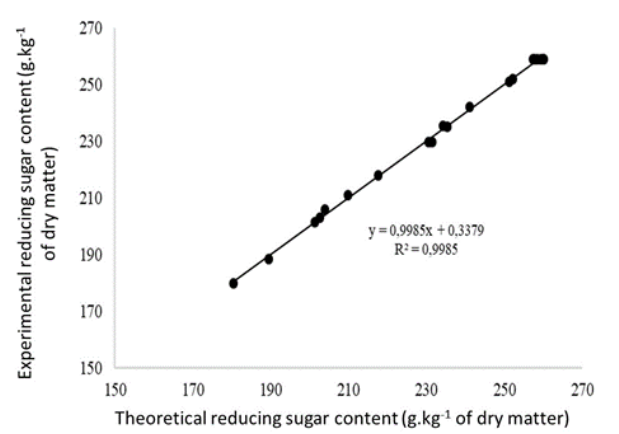

(a)

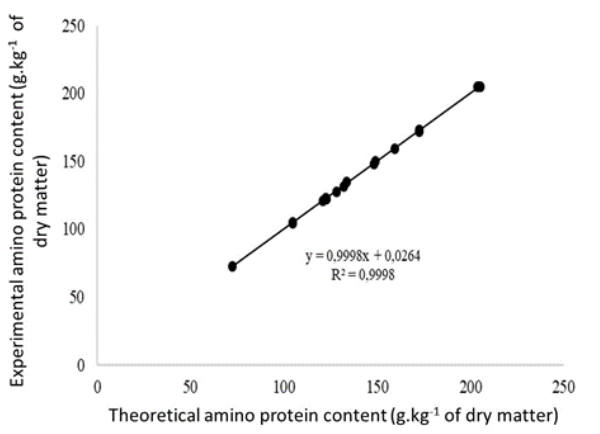

(b)

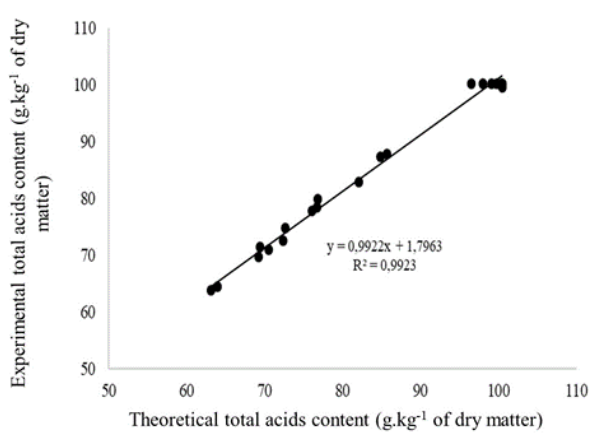

(c)
Figure 2. The compatibility between experimental and theoretical data by regression equation for (a) reducing sugar, (b) amino protein and (c) total acids

The regression equations showing the effect of salt concentration, amount of brine and fermentation time on the content of bioactive compounds ( $\beta$-glucan, total phenolic and total flavonoid) were formulated with a high correlation coefficient $\left(\mathrm{R}^{2}>0.94\right)$, these equations can be used to predict the contents of bioactive compounds at the salt concentration and amount of brine over time of fermentation. In addition, the compatibility of experimental and theoretical values was also determined $\left(\mathrm{R}^{2}>0.99\right)$ (Figure 3).

The response surface models showing the effect of salt concentration, amount of brine and fermentation time on $\beta$-glucan, total phenolic and total flavonoid are presented in Figure 4. Similar to the chemical composition, fermentation parameters affected bioactive compounds. The contents of total $\beta$-glucan, total

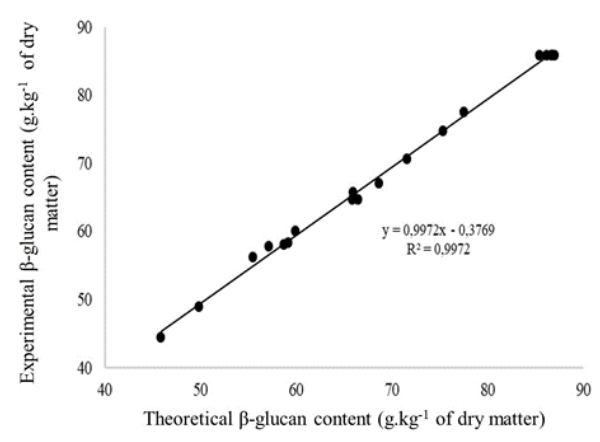

(a)

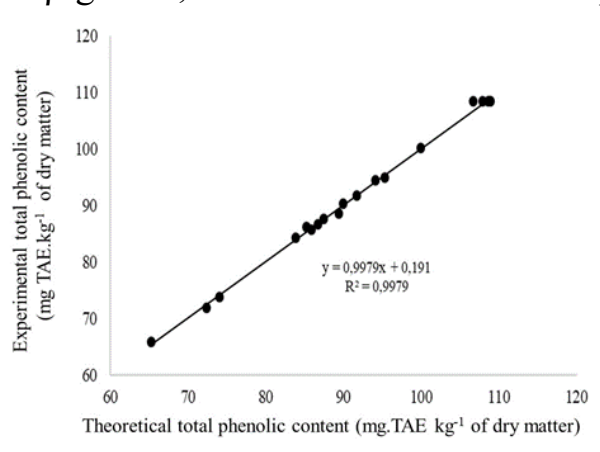

(b) phenolic and total flavonoid tended to increase to the optimal point when increasing the salt concentration, brine ratio and the fermentation time, and then gradually decreased. The optimal results of $\beta$-glucan $(\mathrm{g} / \mathrm{kg}$ of dry matter), total phenolic (mg TAE/kg of dry matter) and total flavonoid (mg QE/kg of dry matter) (respectively) were 86.92, 109.46 and 94.57 when fermenting at a salt concentration of $20.71 \% \mathrm{w} / \mathrm{v}$, the brine ratio of $221.71 \%$ (compared to the raw materials, v/w) for 58.54 days, $21.12 \% \mathrm{w} / \mathrm{v}, 192.45 \%$ for 63.93 days, $20.64 \% \mathrm{w} / \mathrm{v}$, $189.55 \%$ for 63.40 days (respectively). These results showed that the bioactive compounds in sauces were higher when fermented at a salt concentration of $20-22 \%$ $\mathrm{w} / \mathrm{v}$, the $189-222 \%$ of brine (compared to the raw materials, v/w) for a period of 58-64 fermentation days.

The results optimizing many response surfaces had
Figure 3. The compatibility between experimental and theoretical data by regression equation for (a) $\beta$-glucan, (b) total phenolic and (c) total flavonoid

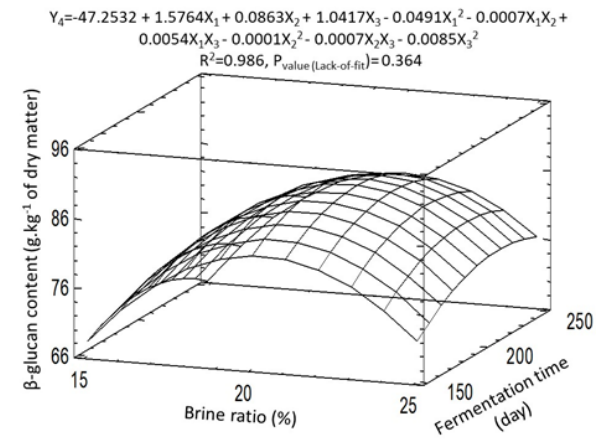

(a)

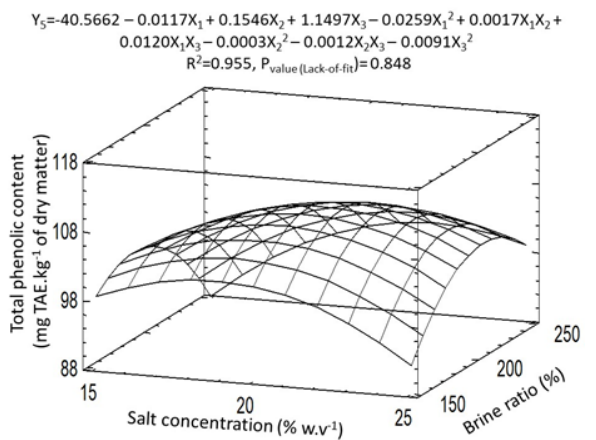

(b)

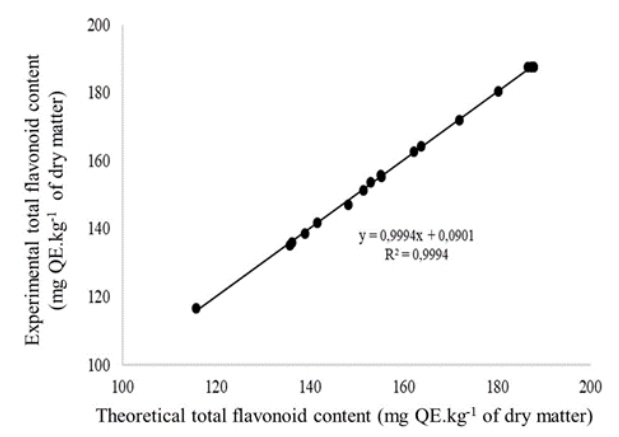

(c) 

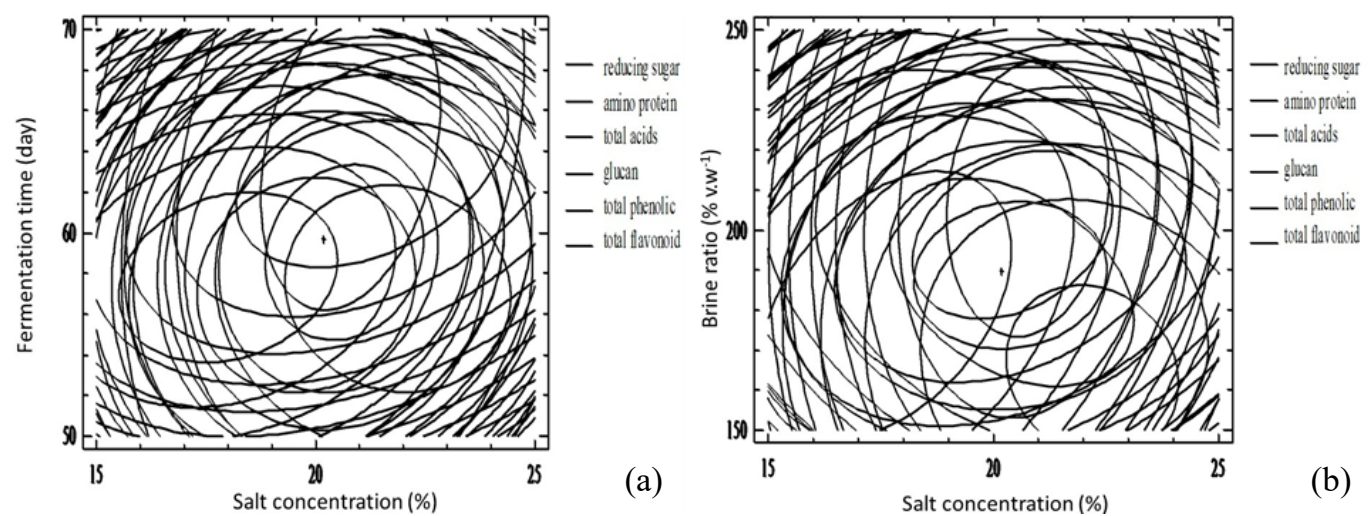

Figure 5. The contour plots of optimization of multiple response surfaces (reducing sugar, amino protein, total acid, $\beta$-glucan, total phenolic and total flavonoid) according to (a) salt concentration and fermentation time, (b) salt concentration and brine ratio (one of which was kept at the central point)

Table 3. The results of experiment and optimization models

\begin{tabular}{cccc}
\hline Target functions & Unit & Values of experiment & Values of optimization models \\
\hline Reducing sugar & $\mathrm{g} / \mathrm{kg}$ of dry matter & $258.94 \pm 0.25$ & 261.71 \\
Amino protein & $\mathrm{g} / \mathrm{kg}$ of dry matter & $204.76 \pm 0.25$ & 206.43 \\
Total acids & $\mathrm{g} / \mathrm{kg}$ of dry matter & $99.06 \pm 0.25$ & 99.04 \\
$\beta$-glucan & $\mathrm{g} / \mathrm{kg}$ of dry matter & $86.57 \pm 0.19$ & 86.26 \\
Total phenolic & $\mathrm{mg} \mathrm{TAE} / \mathrm{kg}$ of dry matter & $108.32 \pm 0.34$ & 107.95 \\
Total flavonoid & $\mathrm{mg} \mathrm{QE} / \mathrm{kg}$ of dry matter & $93.78 \pm 0.09$ & 94.24 \\
\hline
\end{tabular}

Values are presented as mean \pm SD.

found moromi fermentation parameters to the sauce with high chemical and bioactive compounds contents: salt $20.17 \%$, brine ratio $189.83 \%$ for 59.71 fermentation days (Figure 5). With these optimal parameters, in kg dry matter of sauce, the chemical composition (reducing sugar, amino protein, total acids) and the contents of the bioactive compound ( $\beta$-glucan, total phenolic, total flavonoid) were $261.71 \mathrm{~g} ; 206.43 \mathrm{~g} ; 99.04 \mathrm{~g} ; 86.36 \mathrm{~g}$; $107.95 \mathrm{mg}$ TAE and $94.24 \mathrm{mg}$ QE, respectively.

The study conducted an experiment fermenting at $20 \%$ of salt, $190 \%$ of brine ratio with 60 days. The results of the experiment and optimization models are shown in Table 3. The composition of chemical and bioactive compounds from the experiment is equivalent to the values from the optimization models, the difference is about $0.10-1.09 \%$.

\section{Conclusion}

Fermented oyster mushrooms sauce is nutritional as well as functional because of chemical and bioactive compounds. The central composite design and response surface methodology were effectively used to calculate and predict the content of nutrients and bioactive compounds in the fermented sauce. The optimum parameters in moromi fermentation were found at salt concentration $20 \%(\mathrm{w} / \mathrm{v})$, brine volume ratio $190 \%(\mathrm{v} / \mathrm{w})$ and 60 days of fermentation. By application of these results can lead to maximum levels of nutrients and bioactive compounds in oyster mushroom sauce.

\section{Conflict of interest}

The authors declare no conflict of interest.

\section{References}

Baek, L.M., Park, L.Y., Park, K.S. and Lee, S.H. (2008). Effect of starter cultures on the fermentative characteristics of Cheonggukjang. Korean Journal of Food Science and Technology, 40(4), 400-405.

Barros, L., Cruz, T., Baptista, P. and Estevinho, L.M.I.C.F.R. (2008). Wild and commercial mushrooms as source of nutrients and nutraceuticals. Food Chemical Toxicology, 46(8), 2742-2747. https://doi.org/10.1016/j.fct.2008.04.030

Beddows, C.G. (1985). Fermented fish and fish products. In Wood, B.J.B. (Ed). Microbiology of Fermented Foods, p. 1-39. Boston, USA: Springer

Chou, C.C., Hwang, G.R. and Ho, F.M. (1998). Changes of microbial flora and enzyme activity during the aging of Tou-Pan-Chiang, a Chinese fermented condiment. Journal of Fermentation Technology, 66 (4), 473-478. https://doi.org/10.1016/0385-6380(88) 90017-9

Cui, R.Y., Zheng, J., Wu, C.D. and Zhou, R.Q. (2014). Effect of different halophilic microbial fermentation patterns on the volatile compound profiles and sensory properties of soy sauce moromi. European Food Research and Technology, 239, 321-331. https://doi.org/10.1007/s00217-014-2225-9 
Erinç, H., Tekin, A. and Özcan, M.M. (2009). Determination of fatty, tocopherol and phytosterol contents of the oils of various poppy (Papaver somniferum L.) seeds. Grasas Y Aceites, 60(4), 375381. https://doi.org/10.3989/gya.129508

Fournier, E. (2001). Colormetric quantification of carbohydrates. Current Protocols in Food Analytical Chemistry, 00(1), E1.1.1-E1.1.8. https:// doi.org/10.1002/0471142913.fae0101s00

Friedman, M. (2004). Applications of the ninhydrin reaction for analysis of amino acids, peptides and proteins to agricultural and biomedical sciences. Journal of Agricultural and Food Chemistry, 52(3), 385-406. https://doi.org/10.1021/jf030490p

Gao, X., Cui, C., Ren, J., Zhao, H., Zhao, Q. and Zhao, M. (2011). Changes in the chemical composition of traditional Chinese-type soy sauce at different stages of manufacture and its relation to taste. International Journal Food Science Technology, 46(2), 243-249. https://doi.org/10.1111/j.1365-2621.2010.02487.x

Guan, X. and Yao, H. (2008). Optimization of viscozyme $\mathrm{L}$ assisted extraction of oat bran protein using response surface methodology. Food Chemistry, 106(1), 345-351. https://doi.org/10.1016/ j.foodchem.2007.05.041

Hui, Y.H., Meunier-Goddik, L., Hansen, A.S., Josephsen, J., Nip, W.K., Stanfield, P.S. and Toldra, F. (Eds) (2004). Handbook of Food and Beverage Fermentation Technology. $1^{\text {st }}$ ed. New York: CRC Press. https://doi.org/10.1201/9780203913550

Kalac, P. (2009). Chemical composition and nutritional value of European species of wild growing mushrooms. Food Chemistry, 113(1), 9-16. https:// doi.org/10.1016/j.foodchem.2008.07.077

Lee, C.H. and Kim, K.M. (1995). Determination of the shelf-life of pasteurized Korean rice wine, Yakju, in aseptic packaging. Korean Journal Food Science Technology, 27(2), 156-163.

Lopetcharat, K., Choi, Y.J., Park, J.W. and Daeschel, M.A. (2001). Fish sauce products and manufacturing: a review. Food Reviews International, 17(1), 65-68. https://doi.org/10.1081/ FRI-100000515

Lu, Y., Chen, X., Jiang, M., Lv, X., Rahman, N., Dong, M. and Yan, G. (2009). Biogenic amines in Chinese soy sauce. Food Control, 20(6), 593-597. https:// doi.org/10.1016/j.foodcont.2008.08.020

Mathivanan, R., Selvaraj, P. and Nanjappan, K. (2006). Feeding of fermented soybean meal on broiler performance. International Journal of Poultry Science, 5(9), 868-872. https://doi.org/10.3923/ ijps.2006.868.872
Miller, G.L. (1959). Use of dinitrosalicylic acid reagent for determination of reducing sugar. Analytical Chemistry, 31(3), 426-428. https://doi.org/10.1021/ ac60147a030

Mowsumi, F.R. and Choudhury, M.B.K. (2010). Oyster mushroom: biochemical and medicinal prospects. Bangladesh Journal of Medicine Biochemistry, 3(1), 23-28. https://doi.org/10.3329/bjmb.v3i1.13804

Pinelo, M., Sineiro, J. and Nunez, M.J. (2006). Mass transfer during continuous solid-liquid extraction of antioxidants from grape byproducts. Journal of Food Engineering, 77(1), 57-63. https://doi.org/10.1016/ j.jfoodeng.2005.06.021

Pinto, G.A.S., Leitem, S.G.F., Terzi, S.C. and Couri, S. (2001). Selection of tannase-producing Aspergillus niger strains. Brazil Journal Microbiology, 32(1), 24 $-26$. 83822001000100006

Randive, S.D. (2012). Cultivation and study of growth of oyster mushroom on different agricultural waste substrate and its nutrient analysis. Advances in Applied Science Research, 3(4), 1938-1949.

Shieh, Y.S.C., Beuchat, L.R., Worthington, R.E. and Phillips, R.D. (1982). Physical and chemical changes in fermented peanut and soybean pastes containing koji prepared using Aspergillus oryzae and Rhizopus oilgosporous. Journal of Food Science, 47(2), 523529. https://doi.org/10.1111/j.13652621.1982.tb10116.x

Singleton, V.L., Orthofer, R. and Lamuela-Raventos, R.M. (1999). Analysis of total phenols and other oxidation substrates and antioxidants by means of Folin-Ciocalteu reagent. Methods Enzymology, 299, 152-178. https://doi.org/10.1016/S0076-6879(99) 99017-1

Su, N.W., Wang, M.L., Kwok, K.F. and Lee M.H. (2005). Effects of temperature and sodium chloride concentration on the activities of proteases and amylases in soy sauce Koji. Journal of Agricultural and Food Chemistry, 53(5), 1521-1525. https:// doi.org/10.1021/jf0486390

Verma, R.N., Singh, G.B. and Bilgrami, K.S. (1987). Fleshy fungal flora of N.E.H. India - I. Manipur and Megalaya. Indian Mushroom Sciences, 2, 414-421.

Wan, S., Wu, Y., Wang, C. and Hou, L. (2013). The development of soy sauce from organic soy bean. Agricultural Sciences, 4(5), 116-121. https:// doi.org/10.4236/as.2013.45B022

Yang, Y., Deng, Y., Jin, Y., Liu, Y., Xia, B. and Sun, Q. (2017). Dynamics of microbial community during the extremely long-term fermentation process of a traditional soy sauce. Journal of the Science of Food 
and Agriculture, 97(10), 3220-3227. https://

doi.org/10.1002/jsfa.8169

Yokosuka, T. and Sasaki, M. (1998). Fermented protein foods in the Orient with emphasis on shoyu and miso in Japan. In Wood, B.J.B. (Ed). Microbiology of Fermented Foods, p. 351-415. Boston, USA: Springer. https://doi.org/10.1007/978-1-4613-0309$1 \_12$

Zhao, G., Ding, L.L., Yao, Y., Cao, Y., Pan, Z.H. and Kong, D.H. (2018). Extracellular proteome analysis and flavor formation during soy sauce fermentation. Frontiers in Microbiology 9, 1872. https:// doi.org/10.3389/fmicb.2018.01872 